\title{
WP 15-34
}

\author{
Cullen Goenner \\ University of North Dakota, USA
}

Chih Ming Tan

University of North Dakota, USA

The Rimini Centre for Economic Analysis, Italy

\section{MORE CREDIT, MORE PROBLEMS? GOVERNMENT STUDENT LOAN LIMITS AND EDUCATION OUTCOMES}

Copyright belongs to the author. Small sections of the text, not exceeding three paragraphs, can be used provided proper acknowledgement is given.

The Rimini Centre for Economic Analysis (RCEA) was established in March 2007. RCEA is a private, nonprofit organization dedicated to independent research in Applied and Theoretical Economics and related fields. RCEA organizes seminars and workshops, sponsors a general interest journal The Review of Economic Analysis, and organizes a biennial conference: The Rimini Conference in Economics and Finance (RCEF) . The RCEA has a Canadian branch: The Rimini Centre for Economic Analysis in Canada (RCEACanada). Scientific work contributed by the RCEA Scholars is published in the RCEA Working Papers and Professional Report series.

The views expressed in this paper are those of the authors. No responsibility for them should be attributed to the Rimini Centre for Economic Analysis.

The Rimini Centre for Economic Analysis

Legal address: Via Angherà, 22 - Head office: Via Patara, 3 - 47921 Rimini (RN) - Italy

www.rcfea.org - secretary@rcfea.org 


\title{
More Credit, More Problems? Government Student Loan Limits and Education Outcomes
}

\author{
Cullen F. Goenner \& Chih Ming Tan ${ }^{\#}$
}

January 30, 2015

\section{Preliminary and Incomplete.}

\begin{abstract}
The federal Stafford loan program is the largest source of financial aid to students who attend college in the United States. Here we utilize the increase in Stafford loan limits that occurred between 2006 and 2008 to identify how a pooled cross-section of first-time freshmen at the University of North Dakota (UND) responded to an increase in the availability of credit. Using a difference-in-differences approach, we examine how borrowing, the composition of credit, and student outcomes were impacted by the policy changes. The student body at UND provides a unique opportunity to examine the treatment effects of these policies, as we are able to isolate the impact of macroeconomic fluctuations on borrowing due to the strength and stability of the state's economy during the period. Freshmen are shown here to substitute an increase in their borrowing through Stafford loans, with a partial reduction in borrowing via private loans. Substitution is particularly strong among more credit constrained students. Interestingly, despite having access to more credit, student outcomes did not improve as a result of the changes, and in some cases worsened.
\end{abstract}

Keywords: Borrowing constraints; government student loans; education outcomes

JEL Codes: H52, I18

\footnotetext{
${ }^{\#}$ Goenner \& Tan: Department of Economics, College of Business and Public Administration, University of North Dakota, Gamble Hall, 293 Centennial Drive, Grand Forks, ND 58202-8369. Corresponding author (Goenner): cgoenner@business.und.edu.
} 


\section{Introduction}

Since 1993 students have been able to borrow from the federal Stafford loan program without having financial need. Federal statute sets the maximum students are able to borrow each year from the program as the minimum of the loan program's limit and the adjusted cost of attendance. In the more than 45-year history of the program there have been very few changes to the program's limits. Between academic year (AY) 1993-94 and AY 2006-07 the annual loan limit was set at $\$ 2,625$ for freshmen, $\$ 3,500$ for sophomores, and $\$ 5,500$ for juniors and seniors. ${ }^{1}$ During this same time period, the average cost of undergraduate tuition, fees, and room and board doubled from $\$ 6,365$ to $\$ 12,796$ at 4-year public institutions. ${ }^{2}$ As the cost of education has risen, students have increasingly found themselves maxing out their borrowing from government student loan (GSL) programs. ${ }^{3}$ In response, many students have turned to private student loans to supplement their borrowing needs. Between AY 2002-03 and 2005-06 the volume of private-student loans more than doubled from 8.9 billion dollars to 18.7 billion. ${ }^{4}$ Private student loans, unlike Stafford loans require students to be either creditworthy or have a creditworthy cosigner. For students who lack parental support, financing college may be becoming more of a challenge.

As part of the Deficit Reduction Act of 2006, the Stafford loan limit was raised in AY 2007-08 to $\$ 3,500$ for freshmen and $\$ 4,500$ for sophomores, which narrowed the gap between what under and upperclassmen were able to borrow. ${ }^{5}$ Only a year later as the financial crisis and

\footnotetext{
${ }^{1}$ The loan limit for freshmen who qualified based on need (subsidized Stafford loans) has been $\$ 2,625$ since January of 1987. Prior to 1993 there were no unsubsidized loans in the Stafford loan program.

${ }^{2}$ Source: Snyder and Dillow (2013) Digest of Education Statistics 2012 Table 381, U.S. Department of Education.

${ }^{3}$ The percentage of students nationwide who borrowed the annual subsidized Stafford loan program limit increased from $41 \%$ in AY 1995-96 to 51\% in 2003-04, a period in which there were no changes in program limits (Wei and Skomsvold, 2011).

${ }^{4}$ Data is from the College Board's Trends in Student Aid 2013.

${ }^{5}$ The legislation was part of the Higher Education Reconciliation Act of 2005, which is Title 8 of the Deficit Reduction Act of 2005 [Pub. L. No. 109-171, § 8005, 120 Stat. 4, 158 (2006)]
} 
recession hit, Congress responded to tightening credit markets and reduced access to private student loans by increasing the annual Stafford loan limit an additional $\$ 2,000$ for all undergraduate students. Table 1 indicates the historical limits for unsubsidized Stafford loans for undergraduate students by their academic classification. Within a period of two years, freshmen students were able to more than double what they were able to borrow from the federal Stafford loan program.

\section{[Insert Table 1 about here]}

In this paper, we focus on the behavioral response of first-time freshmen who enrolled at the University of North Dakota (UND) in the fall of 2006, 2007, and 2008 to an increase in GSL credit due to the above policy changes in regards to loan limits. A difference-in-differences (DID) estimator is employed to identify the treatment effects of the policy changes. A key challenge in identifying the effect of the loan limit changes is the fact that along with these policy initiatives, there were concurrent confounding shocks occurring in the rest of the macro economy. Over the three-year period examined, the state of the U.S. macro economy shifted quite dramatically. In December of 2007, the U.S. entered the worst recession since the Great Depression. The financial crisis associated with the recession significantly impacted student loan borrowing as the market for asset-backed securities, including private student loans, collapsed. The value of private loans originated declined from 23 billion dollars in AY 2007-08 to 10.7 billion in AY 2008-09. ${ }^{6}$ At the same time, the value of parental assets (equity, real estate) and incomes were in sharp decline as unemployment rose. It was this change in the macro

\footnotetext{
${ }^{6}$ Data is from the College Board's Trends in Student Aid 2013. Student Loan Asset Backed Securities were referred to as SLABS. The creation of SLABS was in large part the reason for the increase (2005-2007) in private student loans.
} 
economy and the impact on the availability and need for credit, which motivated Congress in the first place to increase Stafford loan limits in 2008.

In our dataset a number of these factors (parental income and assets) are observed and can be controlled for, but the state of the economy may impact student behavior in less obvious or unobserved ways. By design, the estimate of the treatment effect under DID is unable to discern between the impact of the policy change and other omitted or unobserved factors that coincide with the timing of the treatment, which may affect the control and treatment groups differently. This could potentially cause an issue with our estimates if unobserved factors caused the borrowing and academic performance of our treated and control groups to respond differently to a macroeconomic shock. For example, students may be more reticent to borrow if the future outlook for the economy in their region is grim, in which case borrowing in 2008 in the midst of the recession, will not only capture the effect of raising credit limits but also the effect of the poor economic outlook on one's unwillingness to borrow. ${ }^{7}$ If the future outlook is different among our control and treatment groups then our estimate of the treatment effect may over or underestimate the true effect of the policy. These differences are likely and likely to be sharp precisely because of the unprecedented nature of the Great Recession in recent memory.

By using data from the University of North Dakota, we are uniquely able to minimize the effects of macroeconomic fluctuations on our estimates of the treatment effect. While much of the United States in 2008 suffered from the recession, the state of North Dakota averaged 8.2\% real growth and 3.2\% unemployment, along with rising home prices. ${ }^{8}$ Hence, while much of the

\footnotetext{
${ }^{7}$ Deaton (1991) demonstrates that in the presence of liquidity constraints if growth rates in income and real GDP are persistent then the onset of an economic downturn signals to individuals (students) that income is expected to fall, and to moderate the impact on future consumption, one should save now to offset the future effects.

${ }^{8}$ Housing prices in North Dakota appreciated in 2008 . The annual $1.89 \%$ increase was the largest in the nation according to data from the FHFA House Price Index for purchases.
} 
country was experiencing a historic negative shock concurrently as the loan limits policies were taking place, the state of North Dakota was enjoying a level of economic stability that more resembled normal times. Therefore it is less likely that these UND students, who are primarily drawn from North Dakota, are impacted by the confounding effects of the Great Recession raging across the rest of the country.

Our results show that freshmen students responded strongly to the policy changes by borrowing more. The 2007 policy change that increased Stafford loan limits by $\$ 875$ for freshmen resulted in their borrowing an additional \$924, relative to the 2006 cohort. Relative to 2006 , the 2008 policy change increased the limit by $\$ 2,875$ and freshmen in the 2008 cohort responded by borrowing an additional $\$ 1,887$ relative to the 2006 cohort. Freshmen not only increased their borrowing as a result of the policy change, but also altered the composition of their student loans. Private student loans decreased by $\$ 425$ and $\$ 564$ as a result of the 2007 and 2008 policy changes. This change in the composition of credit shifted credit risk away from private student loans where parents are cosigners, to federal student loans solely in the student's name. Both credit constrained and un-constrained freshmen took advantage of the changes in policy, though in vastly different ways. Freshmen who were un-constrained due to high expected family contributions to their education, substantially increased their overall borrowing in both periods $(\$ 2,701$ and $\$ 2,858)$ due to the policy changes, whereas constrained (low family contribution) students did not alter their total borrowing due to the 2007 policy change and increased their borrowing by only half the increase seen by un-constrained freshmen in 2008 .

Most interestingly, increasing access to credit, while increasing borrowing did not improve student outcomes. The cumulative GPA of freshmen impacted by the change in the 2007 change in policy was .16 grade points lower than their counterparts in 2006 . With respect 
to credits completed, we find freshmen in 2007 and 2008 completed approximately 1 credit less than the 2006 cohort due to the policy changes. Finally, we did not find any evidence to suggest the increases in the access to credit had an impact on freshmen retention.

The rest of the paper is organized as follows. We provide a literature review in Section 2. Section 3 details our methodology and describes the data. Section 4 discusses our findings. Finally, Section 5 concludes.

\section{Financing Higher Education}

Rising costs of higher education have left policymakers wondering whether a substantial number of students are being priced out of being able to afford an education. As the direct costs of college rise, liquidity constrained students may either defer or forgo college altogether based on the higher direct costs of their education. Students may also choose to attend a lower quality institution or pursue a two-year degree if they are constrained. Research suggests financial aid programs and parental support during the early 1980s were such that borrowing constraints did not appear to matter to educational attainment.

Identifying who is credit constrained though is tough and at best an indirect measure is used with most national data sources, such as the National Longitudinal Survey of Youth, 19792004 (NLSY79). Carneiro and Heckman (2002) make the assertion students whose families are in the top income quartile of the NLSY79 are not liquidity constrained. They evaluate the impact of borrowing constraints by comparing educational outcomes of constrained and unconstrained individuals, when controlling for ability and family characteristics ${ }^{9}$ Their results indicate for white males in the early 1980s there is no significant evidence to suggest credit

\footnotetext{
${ }^{9}$ Carneiro and Heckman control for parental education, number of siblings, and indicator variables for whether from a broken home, the south and urban area. Ability is measured by scores on the armed forces qualification test (AFQT).
} 
constraints influenced the decisions to enroll in college, complete a four-year degree, or enroll in a four-year college over a two-year school. Short-run liquidity constraints they find to be unimportant to education decisions, as compared to long-run measures, such as ability. Cameron and Taber (2004) use NLSY79 data to estimate a model of wages and schooling choice. They similarly find there is no evidence that borrowing constraints affect the likelihood of attending college. The implication from these findings is increasing the amount of grants or loans available to students would not improve outcomes, even among low income, seemingly credit constrained students.

More recent data, from the NLSY97, where students were college age in the late 1990s and early 2000s though indicates income and credit constraints may now play a role in education decisions even in the short-run. Belley and Lochner (2007), using Carneiro and Heckman's (2002) framework and NLSY97 data, find students in the late 90s and early 2000s were more likely to enroll in college the higher their income, and were similarly more likely to enroll in a four-year college, when controlling for ability and family characteristics. They link attainment to income due to students being more dependent on parental transfers to finance the higher price of education, and transfers and income are highly correlated. In such cases, financial aid may be of particular importance to individuals who do not receive transfers, because they are constrained in the aid they receive. Brown, Scholz, and Seshardi (2012) use data on parental cash transfers from the Health and Retirement Study (HRS) to measure whether students who are constrained because they receive no cash transfers are impacted more by a change in financial aid relative to those who are unconstrained. They use the number of college aged children to proxy for the amount of financial aid received and find a credit constrained student with no parental aid and four years of sibling overlap receives an additional .4 years of schooling, relative to a child in the 
same family with no overlap. It is pointed out by Johnson (2013) that a limitation of this finding is that one is unable to determine whether the impact is a result of additional grants or loans. Johnson finds that even if one allowed students to borrow from the government student loan program the full cost of attending college, degree completion would only increase by 2.4 percentage points. He argues the reason there is a relation between income and educational attainment is because it is correlated with parental transfers.

Much of the literature has focused on the effects on educational attainment of borrowing constraints and access to government sponsored loans, and less attention has been paid to the composition of student borrowing. There are three entities in the market for student loans, the largest of which in terms of loan volume is the federal government, followed by private lenders and state agencies. ${ }^{10}$ The loan programs differ in terms of their eligibility requirements and loan terms. There are three federal student loan program - Stafford loan, Perkins Loan, and Parent PLUS Loan. The Stafford Loan Program consists of both subsidized and unsubsidized loans. Perkins loans are also subsidized, which means that while a student is enrolled the borrower does not accrue interest. ${ }^{11}$ Eligibility for both Perkins and subsidized Stafford loans are based on financial need, wherein students who have a lower expected family contribution (EFC) qualify for these need based loans. Unsubsidized Stafford loans are not need based and any student enrolled at a qualified institution is able to borrow the minimum of the statutory limit and the adjusted cost of attendance. ${ }^{12}$ Perkins and Stafford loans, unlike other government and private student loans, are issued in the name of the student and do not require a creditworthy cosigner.

\footnotetext{
${ }^{10}$ In AY 2012-13 the federal government issued 101 billion dollars in loans to undergraduate and graduate students. Private loans amounted to 7.2 billion dollars and state and institution sponsored loans accounted for another 1.6 billion dollars in loans.

${ }^{11}$ The federal government provides funds to schools to originate Perkins loans. Repayment is made to the school, and not the government.

${ }^{12}$ The adjusted cost of attendance includes the price of tuition, room and board, books, and incidentals related to one's education, adjusting for any aid received (scholarships, grants).
} 
The Parent PLUS loan program allows parents without a negative credit history to cosign on a loan for their child up to the adjusted cost of attendance. The credit risk associated with each of the three government loan programs may vary substantially given some loans are given to those in greatest financial need, while others require a creditworthy cosigner.

As the cost of education has risen, students have increasingly found themselves maxing out their borrowing from government student loan (GSL) programs. ${ }^{13}$ In response, many students have turned to private student loans to supplement their borrowing needs. Between AY 2002-03 and 2005-05 the volume of private-student loans more than doubled from 8.9 billion dollars to more than 18.7 billion. ${ }^{14}$ Lochner and Monge-Narango (2011) are able to model this behavior in government and private borrowing and their calibrated policy experiments show private credit markets play an important role in the overall access to credit, as an increase in GSL limits only partially crowds-out private lending. The reason is among the most able students who are credit constrained, the increase in GSL allows for increased investment in human capital, which allows for increased access to funds in the private lending market and additional schooling. In this paper we use a more direct approach to examine the impact of increasing GSL loan limits by evaluating how students responded to the actual change in annual Stafford loan limits implemented for AY 2007-08 and AY 2008-09. This allows us to consider the degree to which students respond to increased access to GSL credit, in terms of the overall amount they borrow and the composition of borrowing between federal and private loans.

\footnotetext{
${ }^{13}$ Stafford loans are subject to an annual borrowing maximum and lifetime maximum. Lochner and MongeNarango examine the impact of the lifetime maximum. Our focus is on the behavior of freshmen, therefore we consider the effects of the annual limit. The percentage of students who borrowed the annual subsidized Stafford loan program limit increased from $41 \%$ in AY $1995-96$ to 51\% in 2003-04, a period in which there were no changes in program limits (Wei and Skomsvold, 2011).

${ }^{14}$ Data is from the College Board's Trends in Student Aid 2013. The value of private loans originated reached a maximum in AY 2007-08 of 23 billion dollars, which declined to 10.7 billion in AY 2008-09. Securitization of student loans through SLABS (Student Loan Asset Backed Securities) drove the increase in 2005-2007.
} 
Private student loans (PSL) are used in conjunction with and perhaps somewhat surprisingly as an alternative to federal Stafford loans. In an analysis of private student loans, the Consumer Financial Protection Bureau and Department of Education find 54\% of PSL borrowers do not use all of their Stafford loan eligibility, which implies for some students PSL are either equivalent to or preferred to federal Stafford loans. In some ways PSL and unsubsidized Stafford loans may appear to students to be similar. Prior to 2008, it was not uncommon for college financial aid packages to directly market both federal and private student loans originated by the same preferred lenders. While PSL and unsubsidized Stafford loans both accumulate interest that is capitalized while a student is in school, PSL loans tend to have variable interest rates whereas GSL are a fixed-rate. This introduces interest rate risk to borrowers of PSL. Using a sample of PSL originated in 2005, the CFPB and Department of Education study shows interest rates for PSL tend to be significantly higher than the Stafford interest rate at the time of origin for everyone other than the most creditworthy borrowers. This 2005 cohort of PSL borrowers though has benefited significantly as interest rates have declined such that the variable rate indexed to LIBOR has fallen below the fixed Stafford rate. When interest rates rise in the future, many with PSL will be faced with higher repayments. It is the conclusion of these policymakers (CFPB and Department of Education) that Stafford Loans should be the preferred choice of most students, and only in cases where families have the financial capacity to pre-pay the variable rate of PSL are they potentially an appropriate substitute.

\section{Model and Data}

The data we use are drawn from a repeated cross section of first-time freshmen students, who enrolled at our institution in the fall semesters of 2006, 2007, and 2008. Our sample only 
includes students who have submitted a Free Application for Financial Student Aid (FAFSA), which is approximately $78 \%$ of the freshmen population in each year. We exclude students who did not file for financial aid because we believe these students are not in the same position as those who do, when it comes to deciding how much to borrow. ${ }^{15}$ In addition, we lack key information on the finances of those who do not file a FAFSA. Not everyone who submits a FAFSA will ultimately borrow, as students may also apply in order to be considered for need based scholarships and grants. In our sample, the fraction of those who submitted a FAFSA and borrowed declined over the three-year period from $81.5 \%$ in 2006 to $76.5 \%$ in 2007 , and $76.8 \%$ in 2009 .

Our analysis, in part, seeks to determine how students' borrowing behavior is impacted by an increase in the availability of credit from the government student loan program. Here we use the temporal variation in Stafford loan limits and cross-sectional variation of borrowing by freshmen to determine the treatment effects of the two policy changes on borrowing. A difference-in-differences estimation strategy is applied where each cohort of freshmen is split into two groups, a treatment group and a control group. The treatment group consists of freshmen who borrowed through the Stafford loan program and as such were potentially impacted by the changes in policy, and the control group consisted of students who borrowed from other sources or who chose not to borrow. Figure 1 depicts the average borrowing by each group over the three years, with the latter two periods reflecting the two policy changes. On average, freshman who borrowed from the Stafford loan program increased their total borrowing from $\$ 6,546$ in AY 2006-07 to \$7,255 in AY 2007-08 and \$8,141 in AY 2008-09. For the control group, however, borrowing declined from $\$ 950$ in AY 2006-07 to \$766 in AY 2007-08

\footnotetext{
${ }^{15}$ We also exclude from the sample, students who were either independent students or aviation majors. Aviation majors face a significantly higher and more variable cost of attendance than other freshmen at our institution. Their cost of attendance depends on the number of flight hours and particular courses enrolled in during the year.
} 
and $\$ 586$ in AY 2008-09. The model of student loan borrowing (y) we use is specified in equation 1 .

$$
y=\alpha+\theta \text { Treat }+\tau_{2007}+\tau_{2008}+\delta_{1} \text { Treat } \otimes 2007+\delta_{2} \text { Treat } \otimes 2008+X \beta+\varepsilon
$$

A group indicator variable is included to control for unobserved differences between the control and treatment groups prior to the policy changes and is captured by $\theta$. Similarly, we add indicator variables for each of the years in which the policy changes were implemented to control for differences in borrowing over time that influence both groups similarly. These effects are captured by the two coefficients for $\tau$ and reflect the impact relative to 2006, i.e. prior to the changes in policy. The coefficients for the interaction terms between groups and time periods $\left(\delta_{1}\right.$ and $\left.\delta_{2}\right)$ captures the treatment effects of the policy changes on borrowing. A vector $(X)$ of student characteristics is added to control for factors that influence the borrowing decision. Summary statistics of these characteristics by control and treatment group for each year appear in Table 2 .

[Insert Figure 1 about here]

Influencing the decision to borrow and how much to borrow is the difference between the cost of attendance and the amount of grants and family transfers a student receives. Grants consist of funds provided to students by institutions and federal and state governments, which typically do not need to be repaid. In some cases, such as the federal Pell Grant, aid is based on financial need, whereas in others it is based on merit, or a combination of both. Institutional support from scholarships is an important tool used by universities themselves to attract students with various targeted characteristics, such as academic ability, athletic ability, ethnic diversity, and socio-economic backgrounds. Our dataset includes information on the dollar amount of the 
various scholarships and grants students receive, but we are unable to directly observe the amount of family transfers.

Family transfers consist of cash contributions to a student's education by family members. To award need based federal aid, the federal government uses a complicated formula and data provided on a student's FAFSA to estimate what a student and their family are reasonably expected to contribute to their son or daughter's education. A dependent student's expected family contribution (EFC) is based primarily on family income, family assets, number of family members, and number of family members in college. In our analysis we use a nonlinear measure, which indicates whether the family's EFC is either between five and ten thousand dollars, between ten and fifteen thousand dollars, or over fifteen thousand dollars. A family EFC less than five thousand dollars serves as our baseline group. Parents though are under no obligation to provide their EFC. To supplement the data we have on the family's EFC, we consider a number of factors that may influence parents' actual contributions. Students with high ability, as measured by ACT scores, are more likely to have parents who invest in their child early in life, and are thus more likely to provide for their child's investment in higher education. First-generation college students may be more likely to have parents who underinvest in their son or daughter's education and thus they are more reliant on borrowing to finance their education. We also posit here that one may be able to ascertain parents' willingness to support their child's education by a student's earnings. Students who work a large number of hours, thus earning more income while in school demonstrate a great deal of financial independence. This independence is brought upon by either an unwillingness of students to seek additional transfers from their parents, or an inability of parents to contribute transfers. In either case, the more students earn the less likely they are to receive transfers and the more they may need to borrow. 
[Insert Table 2 about here]

Students borrow out of financial need, but their need may be dependent on their perception of the costs and returns to their education and level of financial literacy. ${ }^{16}$ We have no way of directly measuring either student perceptions or financial literacy, so we use their family socio-economic status, as measured by family income for a proxy. The control variables for academic ability and first-generation status may also influence literacy, with financial literacy increasing with ability and parental education. We would expect more financially literate individuals to borrow less, ceteris paribus. Our model of borrowing also controls for whether students are residents of North Dakota and Minnesota. Due to tuition reciprocity agreements between North Dakota and Minnesota, students from these two states have a significantly lower cost of attendance than students from other states. We also include whether a student graduated from one of the sixteen high schools located thirty or less miles to our University, where the idea is these students face fewer expenses due to the proximity of their hometowns. ${ }^{17}$ It is also possible that proximity to our institution increases parents' awareness of the likelihood of their child to attend our institution and their need to provide financial support. Our final control, serves as an indirect measure of student motivation and interest. During the recruitment process, our institution kept track of the number of times in which students on their own initiated contact with the institution. We consider whether the level of student engagement as captured by contact count may influence borrowing behavior.

\footnotetext{
${ }^{16}$ We also examined the impact of gender, minority status, family size, age, and high school grade point average, none of which were found to have an effect.

${ }^{17}$ Card (2001) provides discussion how proximity to college can serve as an instrumental variable for the level of schooling.
} 
A potential concern is whether there is a relationship between the timing of the policy changes and unobserved factors that effect borrowing, which would introduce a bias into our estimates of the treatment effect. If students knew they would not be financially supported by their parents independent of income and EFC, they may systematically defer attending college in 2006 and decide to enroll in either 2007 or 2008, when their individual borrowing capacity increased. In this case, we would see a strong response in borrowing by freshmen during the policy years that was caused by an unobservable factor, lack of family support, and not driven by increased access to credit. If this were the case, one would expect the age of students who are borrowing to increase due to their deferral of college, and more students would borrow. As noted above, during the policy years freshmen were less likely to apply for aid, and those who did were less likely to borrow. Further, the average age of borrowers was 19.6 years in each of the three periods. It does not appear that deferrals due to borrowing considerations had an impact on our sample over time.

Another concern is whether the economic recession that began at the end of 2007 may have impacted some students at our institution differently than others based on unobserved characteristics. Students at the University of North Dakota are relatively homogenous, with $48 \%$ of the freshmen cohort being drawn from North Dakota and 44\% from Minnesota. ${ }^{18}$ Drawn primarily from our region, freshmen and their families we argue were largely isolated from the macroeconomic shock that hit the rest of the economy during the recession. Figure 2 a depicts the seasonally adjusted monthly unemployment rate for North Dakota relative to the United States. From the figure it is quite evident that North Dakota's unemployment rate was relatively unaffected by the recession, when at the same time unemployment nationwide would reach $10 \%$

\footnotetext{
${ }^{18}$ The campus of the University of North Dakota is located in Grand Forks and is approximately three miles from the border with Minnesota.
} 
in October of 2009. Similarly, if we examine Figure $2 \mathrm{~b}$ one will note the average annual real GDP growth during calendar years $2006-2009$ was $4.2 \%$ in North Dakota compared to .23\% for the country. Another key economic factor during the recession, was the impact the financial crisis had on housing prices. While housing prices in the United States began their decline in the third quarter of 2007 and continued through the first quarter of 2011, housing prices in North Dakota rose steadily through most of the period as seen in Figure 2c. Our institution was financially strong during this period, due to a substantial budget surplus. As a result, the price of tuition and fees for residents of North Dakota and Minnesota rose by only $\$ 383$ in 2007 and another \$213 in 2008.

[Insert Figure 2 about here]

\section{Results and Discussion}

\subsection{Impact on Total Borrowing}

Our baseline specification of equation 1 excludes two of the variables discussed above. It is possible that the increase in Stafford loan limits influenced the number of first-generation students who enrolled, which could create endogeneity issues. Similarly, students who made more contact with our institution prior to enrollment, may have been more likely to learn about and take advantage of the changes in financial aid. The baseline results appear in column 1 of Table 3, with robust standard errors clustered by high schools. In 2007 Stafford loan limits for freshmen increased by $\$ 875$ and our estimate of the treatment effect indicates freshmen increased their borrowing by $\$ 924$, relative to the 2006 cohort, with the result significant at the $1 \%$ level. The 2008 policy change increased Stafford limits by $\$ 2,875$, relative to 2006 , and borrowing increased by $\$ 1,887$, with the result also significant at the $1 \%$ level. 


\section{[Insert Table 3 about here]}

The results show us for every $\$ 1,000$ in additional scholarships received, freshmen borrowed $\$ 242$ less, when controlling for other factors. Students with expected family contributions (EFC) between $\$ 5,000$ and $\$ 10,000$ borrow on average $\$ 798$ more than those with parental EFCs less than $\$ 5,000$. It appears the ability to borrow is important to this group to pay for college. For the two higher EFC groups, there is no impact on borrowing behavior. Increasing ability, as measured by a 1 standard deviation in ACT score, decreases borrowing by \$100. Not surprisingly, residents of Minnesota and North Dakota who face lower tuition than residents from other states, borrowed $\$ 1,499$ less than students without reciprocity. Further we find students who graduated from a high school in these two states within 30 miles of our institution borrowed $\$ 777$ less. The marginal effect of the other variables were small, where statistically significant.

To evaluate the sensitivity of our results, we conduct a number of robustness checks. In the first we consider a falsification test, in which we split our original control group that consisted of non-Stafford borrowers and non-borrowers into a control group of non-borrowers and a fake treatment group of non-Stafford borrowers. If our revised treatment group is indeed fake, then we would expect our difference in difference estimates to not be significantly different than zero. Our results confirm this, as both treatment effects are not significantly different than zero under the falsification test with estimates appearing in Appendix Table 1 column 1 . We also examined several different comparison groups, to determine whether the estimates were sensitive to construction. Column 2 in Appendix Table 1, reports results from using a treatment group consisting of Stafford borrowers, and a control group of non-borrowers. Our estimates of the treatment effect are slightly smaller than our baseline model, with an estimated impact of 
$\$ 814$ due to the 2007 policy change and $\$ 1667$ due to the 2008 policy change. Both estimates are statistically significant at the $1 \%$ level. Using non-Stafford borrowers alone as our control group, we find in Appendix Table 1 column 3 the effect of the 2007 policy change to be significantly reduced and not statistically significant. The impact of the 2008 policy change $(\$ 1,604)$ though is in line with our other results and is significant at the 5\% level.

To further test the sensitivity of our baseline model, we use our baseline model's control and treatment groups and add to the specification the first-generation and contact count variables. The results in column 2 of Table 3 are similar to our baseline findings, with first-generation freshmen borrowing on average $\$ 384$ more than similar counterparts and contact count not having a significant effect. Adding other demographic factors, such as gender, ethnicity, family size, age, and high school grade point average were found not to be statistically significant and did not impact our results. ${ }^{19}$ A potential concern is whether freshmen who enrolled in 2008, may have chosen to enroll at a lower cost state school such as ours, only as a result of the credit crunch. If this were the case, our 2008 sample may differ in unobserved ways. To discern whether freshmen in 2008 were "settling" in their choice to attend UND, we use the order in which students list where to send their ACT scores as a proxy for their preferences. Students generally take their ACT during their junior year, therefore their preference sorting was established prior to the recession. In both 2006 and 2008 freshmen cohorts, $61 \%$ of students indicated UND was their first choice, with similar mean ordering between the two years. UND's position in the ordering of ACT scores was found not to effect borrower behavior, when added to the baseline model. The effect of the 2007 policy change was diminished to $\$ 623$, while the

\footnotetext{
${ }^{19}$ These results are available upon request.
} 
2008 change of $\$ 1,652$ was similar to our other findings. These estimates appear in column 3 of Table 3.

As a final robustness check we verified that our results were robust to bias due to differences in the distribution of observed characteristics across the treatment and control groups; i.e., lack of covariate balance. We used matching to pair freshmen from the treatment and control groups that have similar observed characteristics. A separate propensity score is used to match observations from AY 2006-07 to those in AY 2007-08 and similarly between AY 2006-07 and AY 2008-09. Each score is estimated via a logit model of the probability of borrowing from the Stafford loan program, where we condition on the same controls used in our baseline specification. Using kernel density weights on the common support, we estimate the differencein-differences using the matched samples, where standard errors were bootstrapped using 100 iterations. The results from matching in column 4 of Table 3 indicate the 2007 change in policy increased borrowing by $\$ 1001$, and the change in 2008 had an effect of $\$ 1,897$, which are both in line with our baseline results.

\subsection{Impact on the Composition of Borrowing}

The results above focused on the impact GSL limits had on total borrowing. Also of interest is whether the change in Stafford loan limits had an impact by crowding out borrowing from private lenders. The results in Table 4 use the same treatment and control groups as our baseline model and consider the impact on borrowing from private lenders. The treatment effect of the 2007 policy change was to reduce private loans by $\$ 425$ relative to the 2006 cohort, which was significant at the 5\% level. For 2008, borrowing from private lenders declined by $\$ 564$ relative to the 2006 cohort and was significant at the $1 \%$ level. In each case the decrease in private borrowing was only partially crowded out by the changes in GSL limits. Similar to 
before we run a series of robustness checks on our estimates. The results of our falsification test, in which the treatment group consists of non-Stafford borrowers and the control group nonborrowers, indicates as expected there was no impact of either policy change. ${ }^{20}$ Using again a treatment group made up of Stafford loan borrowers and a control group of non-borrowers, we find slightly larger impacts than the baseline results. The 2007 policy change reduces private borrowing by $\$ 484$ and the 2008 change by $\$ 658$. When we compare the same treatment group, with the control group that consists of non-Stafford borrowers, the effects are again negative (\$535 and \$521, respectively), but are not significant due to the substantial standard errors. Implementing a similar matching procedure as before, we find the policy change in 2007 had a smaller impact than our baseline model (\$360), which was significant at the $10 \%$ level. The estimate of the 2008 treatment effect was slightly larger than the baseline, and the result was significant at the $5 \%$ level. Given these mixed results it appears the increase in GSL limits at most partially crowded out private borrowing, and may have had a negligible effect.

\section{[Insert Table 4 about here]}

From a policy perspective, a concern with the expansion of the GSL program is whether the increase in borrowing by freshmen is on the basis of need or the availability of easy credit. If students borrowed on the basis of need, one would expect a stronger response from the policy change of those who are most in need. Without data on family transfers, we are unable to directly measure a student's financial need, but we might expect students whose parents have a high EFC to have lower need. Given unsubsidized Stafford loans are not need based it is possible the change in policy affected borrowers who were liquidity constrained due to need, differently than those who were not. Here we identify students with financial need to have an

\footnotetext{
${ }^{20}$ These results and those for the control group split appear in Appendix 2.
} 
EFC less than $\$ 23,000$, which places them below the upper quartile of the student body and is approximately the cost of attending our institution. To identify the effect of need on the impact of the policy changes, we add five variables to the specification that interact the EFC indicator with the treatment group, the year effects, and the treatment effects.

$$
\begin{aligned}
y= & \alpha+\theta \text { Treat }+\gamma E F C+\tau_{2007}+\tau_{2008}+\delta_{0} E F C \otimes \text { Treat }+\delta_{1} \text { Treat } \otimes 2007+ \\
& \delta_{2} \text { Treat } \otimes 2008+\delta_{3} E F C \otimes 2007+\delta_{4} E F C \otimes 2008+\delta_{5} E F C \otimes \text { Treat } \otimes 2007+ \\
& \delta_{6} E F C \otimes \text { Treat } \otimes 2008+X \beta+\varepsilon
\end{aligned}
$$

The treatment effect of the 2007 policy change on those with need (low EFC) is captured by coefficients $\delta_{1}+\delta_{5}$ and the effect on those without need is given by $\delta_{1}$. Similarly, the treatment effect of the 2008 policy change is given by $\delta_{2}+\delta_{6}$ and $\delta_{6}$. The results from Table 5 indicate the policy changes affected high and low EFC freshmen borrowers differently, with surprisingly a larger impact on overall borrowing among high EFC borrowers. For the 2007 policy change the treatment effect on low EFC households is equal to $\$ 334$, which is not statistically different than zero. For 2008, low EFC household's borrowed an additional $\$ 1,489$ as a result of the policy change. The impact was larger among high EFC students as total borrowing rose by $\$ 2,701$ and $\$ 2,859$ due to the 2007 and 2008 policy changes. Students with the least need as indicated by potential family support responded the most strongly to changes in Stafford loan limits. Examining the impact on private loans (Table 5, column 2) we discover another interesting finding as it relates to private borrowing. Among low EFC students, the change in 2007 loan limits had no statistically measureable impact on their overall borrowing, but with respect to private borrowing we see there is a reduction of private borrowing by $\$ 597$, which is statistically significant at the 5\% level (p-value .0313). Similarly, in 2008 low EFC students reduced their private borrowing by $\$ 614$ (p-value .0218). Based on these results it 
appears low EFC students used the additional GSL credit to adjust their composition of borrowing away from private loans, whereas unconstrained students took advantage of easy access to credit to increase consumption.

[Insert Table 5 about here]

\subsection{Impact on Student Outcomes}

We next turn our attention to whether the changes in GSL limits had an impact on student outcomes. The outcomes we consider are a student's cumulative grade point average (GPA) at the completion of their freshmen year, their credits completed, and whether they failed to return for their sophomore year. The latter measure is often referred to as a student stopping out. A similar difference-in-differences framework is used as before, with our treatment group consisting of freshmen who borrow from the Stafford loan program and the control group consisting of non-Stafford borrowers and non-borrowers. Figure 3 depicts the mean for each performance measure and group before and after the change in policy. For our baseline specification of student outcomes we include the same variables used in the baseline model of borrowing and add control variables for a student's high school GPA, and whether they are female, or a minority student.

[Insert Figure 3 about here]

Table 6 column 1 displays the results of our baseline model for a student's cumulative grade point average. The treatment effect of the 2007 change in GSL limits is to reduce on average a student's GPA by 16 grade points relative to the GPAs of the 2006 cohort. What this result implies is freshmen, who had a greater ability to borrow from the GSL program due to the policy change, performed academically worse than their counterparts the year before. The 
impact of the 2008 policy change, while negative is not found to be significant at the $10 \%$ level (p-value .138). Demographic factors and parental income had a larger impact on student performance than borrowing. The results indicated female students perform significantly better and minority students significantly worse by a magnitude of .29 grade points. Increasing a family's EFC also played an important role, as academic performance steadily increased for each of the groups.

Similar to before we considered a number of robustness checks. A falsification test in which the treatment group consisted of non-Stafford borrowers and the control group was nonborrowers rejected their being any difference between the two groups. ${ }^{21}$ Further robustness checks using the separate control groups (non-borrowers \& non-Stafford borrowers) are also provided to evaluate the sensitivity of our results. In both instances, we find evidence of an effect of the 2007 policy change lowering academic performance. Using the non-borrowers as our control group the treatment effect is .14 , whereas for the control group of non-Stafford borrowers the effect is -.29 . A potential concern one might have is whether the lower performance witnessed in 2007 was a result in a shift of major choices by freshmen Stafford borrowers to more challenging majors. In an attempt to control for this we add to our baseline model a variable indicating whether a student was a science, technology, engineering, or math (STEM) major, given the potential such students may enroll in more challenging courses their freshmen year. We also added to this specification our first-generation and contact count measures. Major choice did not appear to have an impact as the measure was not statistically significant and our estimates (Table 6, column 2) of the treatment effect were unchanged. Firstgeneration students performed slightly worse, though the marginal effect while statistically

\footnotetext{
${ }^{21}$ These results and those for the control group split appear in Appendix 3.
} 
significant was negligible at .06 grade points. Increasing contact counts by 1 standard error (4.6 contacts) improved one's GPA by .12 grade points. Results from our matching on common support with the kernel propensity score showed the impact of the 2007 policy change to be slightly larger in magnitude, reducing GPA by .18 grade points, with no significant effect in 2008.

[Insert Table 6 about here.]

With respect to credits completed the results of our baseline model in Table 7 suggest both the 2007 and 2008 policy changes had a negative impact on student outcomes, relative to the 2006 cohort. The treatment effect of the 2007 policy change was to reduce the average number of credits completed by 1.1 , which is quite substantial given the average number completed is approximately 26 . The same sized effect is found due to the 2008 policy change, with both of the effects statistically significant at the $10 \%$ level. Demographics again played a role in credits completed, with women completing on average 1.8 more credits and minorities nearly 3 credits ( 1 course) less per year than other freshmen. The falsification test indicates as expected that there was no significant effect of fake treatment. ${ }^{22}$ Using the separate control groups, the standard errors of our estimated treatment effects increase. With non-borrowers as our control group, the estimate of the treatment effect is -.81 , which is not statistically significant (p-value .23). For the 2008 estimate the result is -1.12 and is similar to before and significant at the $10 \%$ level. When non-Stafford borrowers are used as the control group the treatment effect of the 2007 change is magnified, with an estimate of -2.99 that is statistically significant at the $5 \%$ level. The estimated effect of the 2008 policy is similar to our baseline results at .97 , but the large standard error results in an insignificant finding (p-value .50).

\footnotetext{
${ }^{22}$ These results and those for the control group split appear in Appendix 4.
} 
Each of the three variables (contact counts, first-generation status, and STEM major) added to the baseline specification were significant at the $10 \%$ level. STEM majors were likely to complete $1 / 2$ less credits per year than other majors, while first-generation college students completed .65 credits less and each additional contact increased credits completed by .20 . The estimates of the treatment effects were similar to those we found in the baseline model, with effects significant at the $10 \%$ level. When we use the matching estimator the estimate of the treatment effects are slightly larger in magnitude than the baseline model. The 2007 policy change decreased credits completed by 1.2 , which was significant at the $10 \%$ level. For the 2008 estimate, the treatment effect is to reduce credits completed by 1.35 , which was significant at the $5 \%$ level.

[Insert Table 7 about here.]

In our final analysis we examine whether the changes in GSL limits had an impact on freshmen retention. A binary indicator is our dependent variable, which takes a value of one if a student did not re-enroll for the start of their sophomore year (stop out). Twenty percent of the 2006 freshmen cohort did not return for their sophomore year. Of the 2007 cohort, sixteen percent of freshmen did not return, and $20 \%$ did not return in 2008. The results of our baseline model estimated using logistic regression indicate in Table 8 the policy changes that eased borrowing constraints did not have an impact on whether freshmen were retained, a finding supported by Stinebrickner and Stinebrickner's (2008) results for students at Berea College. The results of our falsification tests and alternative control groups also did not find any support to 
suggest the changes in policy impacted freshmen retention. ${ }^{23}$ Similarly, the use of a matched sample did not uncover evidence of an impact due to either policy change.

\section{Conclusion}

In this paper, we consider the effects of changes in Stafford loan limits in 2007 and 2008 compared to the benchmark year of 2006 on the behavior and outcomes of first-time freshmen students at the University of North Dakota. The North Dakota setting is of interest because, while the rest of the country was entering the historic Great Recession in 2007 and 2008, the state of North Dakota continued to enjoy economic growth that was consistent with times of fullemployment in the national business cycle. The North Dakota context, therefore, allowed us to isolate the effects of the policy changes from the confounding influence of a concurrent economic shock of historic proportions.

We find that, relative to the benchmark 2006 cohort, the increase in Stafford loan limits led to an increase in total borrowing comparable to $65-100 \%$ of the total increase in loan limits. There is some evidence that the increase in Stafford loan limits led to a partial crowding out of borrowing from private lenders as some students substituted Federal loans for private loans. However, in this case, the treatment effect also exhibited substantial heterogeneity with students who expect low family contributions using the additional loan access to substitute for private loans while financially unconstrained students used the additional credit simply to increase consumption. In terms of student academic outcomes, the impact of the increase in Stafford loan limits was largely negative in terms of GPA scores. Hence, while this policy may have led to some welfare improvements for poorer students who would otherwise have had to accept

\footnotetext{
${ }^{23}$ These results and those for the control group split appear in Appendix 5.
} 
potentially less favorable terms from private lenders, the benefits of the policy have to be weighed against the finding that the overall set of outcomes from this policy largely do not conform to its intended goals. 
Table 1: Stafford Loan Program Maximum Annual Limits, AY 1993-94 to 2008-09

Combined Subsidized and Unsubsidized Loans Totals

$\begin{array}{cccccc}\text { Academic Year } & \text { Freshmen } & \text { Sophomores } & \text { Juniors } & \text { Seniors } & \text { Cumulative } \\ \text { Total }\end{array}$


Table 2: Data Summary of Means

\begin{tabular}{|c|c|c|c|c|c|c|c|c|c|}
\hline \multirow[b]{2}{*}{ Variable } & \multicolumn{2}{|c|}{ AY 2006-07 } & & \multicolumn{2}{|c|}{ AY 2007-08 } & \multicolumn{4}{|c|}{ AY 2008-09 } \\
\hline & Control & Treatment & & Control & Treatment & & Control & Treatment & \\
\hline Close Proximity & 0.14 & 0.16 & & 0.22 & 0.16 & $* *$ & 0.12 & 0.16 & \\
\hline ACT score & 24.40 & 22.85 & $* * *$ & 24.60 & 23.27 & $* * *$ & 24.50 & 23.00 & $* * *$ \\
\hline First Generation & 0.20 & 0.23 & & 0.16 & 0.22 & $*$ & 0.16 & 0.21 & $* *$ \\
\hline Number of Contacts & 3.14 & 2.82 & $* * *$ & 6.63 & 6.26 & $* *$ & 5.08 & 4.54 & $* * *$ \\
\hline ND/MN Resident & 0.91 & 0.93 & & 0.90 & 0.92 & & 0.90 & 0.90 & \\
\hline Parental Income (\$1000) & 92.14 & 77.82 & $* * *$ & 95.82 & 79.52 & $* *$ & 113.99 & 84.70 & $* * *$ \\
\hline Student Income (\$1000) & 2.62 & 2.97 & & 2.47 & 3.02 & $* *$ & 3.03 & 3.38 & \\
\hline Scholarships Received & 2489.17 & 1767.97 & $* * *$ & 2.96 & 2.02 & $* * *$ & 3.09 & 2.05 & $* * *$ \\
\hline $\mathrm{EFC}<=5 \mathrm{~K}$ & 0.19 & 0.26 & $* *$ & 0.20 & 0.26 & $*$ & 0.14 & 0.24 & $* * *$ \\
\hline $5 \mathrm{~K}<\mathrm{EFC}<=10 \mathrm{~K}$ & 0.13 & 0.21 & $* *$ & 0.11 & 0.22 & $* * *$ & 0.10 & 0.18 & $* * *$ \\
\hline $10 \mathrm{~K}<\mathrm{EFC}<=15 \mathrm{~K}$ & 0.13 & 0.20 & $* *$ & 0.13 & 0.17 & & 0.08 & 0.18 & $* * *$ \\
\hline $15 \mathrm{~K}<\mathrm{EFC}$ & 0.56 & 0.34 & $* * *$ & 0.56 & 0.35 & $* * *$ & 0.68 & 0.40 & $* * *$ \\
\hline Female & 0.51 & 0.55 & & 0.53 & 0.52 & & 0.53 & 0.53 & \\
\hline Minority & 0.05 & 0.03 & & 0.03 & 0.04 & & 0.06 & 0.04 & \\
\hline Age & 19.58 & 19.61 & & 19.59 & 19.60 & & 19.57 & 19.59 & \\
\hline Family Size & 4.04 & 4.02 & & 4.04 & 4.02 & & 4.07 & 4.00 & \\
\hline High School GPA & 3.50 & 3.40 & $* * *$ & 3.53 & 3.39 & $* * *$ & 3.53 & 3.35 & $* * *$ \\
\hline ACT Ordering & 1.77 & 1.73 & & 1.59 & 1.56 & & 1.76 & 1.64 & \\
\hline STEM major & 0.30 & 0.19 & $* * *$ & 0.27 & 0.21 & $* *$ & 0.29 & 0.23 & $*$ \\
\hline
\end{tabular}

Note: Two sample t-test of control and treatment group difference in means with equal variances $*, * *, * * *$ Statistically different from zero at the $10 \%, 5 \%$, and $1 \%$ level 
Table 3: Impact on Freshmen Total Borrowing

\begin{tabular}{|c|c|c|c|c|}
\hline & $(1)$ & $(2)$ & (3) & $(4)$ \\
\hline Close Proximity & $\begin{array}{c}-777.4331 * * * \\
(166.2623)\end{array}$ & $\begin{array}{c}-800.1149 * * * \\
(180.2326)\end{array}$ & $\begin{array}{c}-714.4018 * * * \\
(184.5730)\end{array}$ & \\
\hline ACT Score & $\begin{array}{c}-100.0509 * * * \\
(17.3159)\end{array}$ & $\begin{array}{c}-97.3459 * * * \\
(18.0432)\end{array}$ & $\begin{array}{c}-95.5926^{* * *} \\
(20.1120)\end{array}$ & \\
\hline ND/MN Resident & $\begin{array}{c}-1499.3342 * * * \\
(360.1793)\end{array}$ & $\begin{array}{c}-1487.8711 * * * \\
(360.4873)\end{array}$ & $\begin{array}{c}-1525.5963 * * * \\
(440.2001)\end{array}$ & \\
\hline Parental Income (\$1000) & $\begin{array}{l}-1.0489 \\
(1.7787)\end{array}$ & $\begin{array}{c}-0.8578 \\
(1.7664)\end{array}$ & $\begin{array}{l}-0.4121 \\
(2.0638)\end{array}$ & \\
\hline Student Income $(\$ 1000)$ & $\begin{array}{c}38.0159 * * * \\
(13.5798)\end{array}$ & $\begin{array}{c}36.5930 * * * \\
(13.6435)\end{array}$ & $\begin{array}{c}22.1408 \\
(18.8646)\end{array}$ & \\
\hline Scholarships $(\$ 1000)$ & $\begin{array}{c}-241.9485 * * * \\
\quad(27.2412)\end{array}$ & $\begin{array}{c}-243.6133 * * * \\
(27.2462)\end{array}$ & $\begin{array}{c}-248.7996^{* * *} \\
(30.4847)\end{array}$ & \\
\hline $5 \mathrm{~K}<\mathrm{EFC}<=10 \mathrm{~K}$ & $\begin{array}{c}798.2903 * * * \\
(219.6029)\end{array}$ & $\begin{array}{c}813.6268 * * * \\
(221.7068)\end{array}$ & $\begin{array}{c}660.7092 * * * \\
(245.4580)\end{array}$ & \\
\hline $10 \mathrm{~K}<\mathrm{EFC}<=15 \mathrm{~K}$ & $\begin{array}{c}173.4033 \\
(245.2607)\end{array}$ & $\begin{array}{c}205.4620 \\
(249.2747)\end{array}$ & $\begin{array}{c}110.3075 \\
(261.3664)\end{array}$ & \\
\hline $15 \mathrm{~K}<\mathrm{EFC}$ & $\begin{array}{l}-127.4002 \\
(267.6556)\end{array}$ & $\begin{array}{c}-82.8199 \\
(262.1774)\end{array}$ & $\begin{array}{l}-292.1443 \\
(286.7618)\end{array}$ & \\
\hline Treatment Group & $\begin{array}{c}5063.4598 * * * \\
(222.6733)\end{array}$ & $\begin{array}{c}5059.3993 * * * \\
(221.4566)\end{array}$ & $\begin{array}{c}5130.1955^{* * *} \\
(215.5067)\end{array}$ & \\
\hline Group X 2007 & $\begin{array}{c}923.5275 * * * \\
(289.9606)\end{array}$ & $\begin{array}{c}912.2610 * * * \\
(285.2150)\end{array}$ & $\begin{array}{c}623.6836^{* *} \\
(299.4062)\end{array}$ & $\begin{array}{c}1000.621 * * * \\
(278.600)\end{array}$ \\
\hline Group X 2008 & $\begin{array}{c}1886.7703 * * * \\
(284.9976)\end{array}$ & $\begin{array}{c}1875.8095 * * * \\
(283.5472)\end{array}$ & $\begin{array}{c}1652.1942 * * * \\
(319.7239)\end{array}$ & $\begin{array}{c}1897.217 * * * \\
(314.541)\end{array}$ \\
\hline Year 2007 & $\begin{array}{c}-15.1080 \\
(233.4403)\end{array}$ & $\begin{array}{c}33.8784 \\
(259.6718)\end{array}$ & $\begin{array}{c}311.7078 \\
(272.7051)\end{array}$ & \\
\hline Year 2008 & $\begin{array}{l}-167.3042 \\
(231.1353)\end{array}$ & $\begin{array}{l}-133.3656 \\
(236.9552)\end{array}$ & $\begin{array}{c}72.6401 \\
(256.7077)\end{array}$ & \\
\hline First Generation & & $\begin{array}{l}383.7967 * \\
(203.9214)\end{array}$ & & \\
\hline Number of Contacts & & $\begin{array}{l}-10.5964 \\
(38.0087)\end{array}$ & & \\
\hline ACT Ordering & & & $\begin{array}{c}64.7255 \\
(77.6039)\end{array}$ & \\
\hline Constant & $\begin{array}{c}5492.9315 * * * \\
(546.9672)\end{array}$ & $\begin{array}{c}5337.5670 * * * \\
(547.8359)\end{array}$ & $\begin{array}{c}5286.1503 * * * \\
(655.3045)\end{array}$ & \\
\hline Observations & 2961 & 2961 & 2246 & $1915 ; 2000$ \\
\hline Adjusted R-squared & 0.422 & 0.423 & 0.422 & $.313 ; .375$ \\
\hline
\end{tabular}

Note: Robust standard errors clustered by high school appear in parentheses $*, * *, * * *$ Statistically different from zero at the $10 \%, 5 \%$, and $1 \%$ level

(4) PSM ran separately on the $2006 \& 2007$ samples and $2006 \& 2008$ samples. Standard errors 
of PSM are bootstrapped using 100 iterations and clustered by high school. 
Table 4: Impact on Freshmen Private Loan Borrowing

\begin{tabular}{|c|c|c|c|}
\hline & $(1)$ & $(2)$ & (3) \\
\hline Close Proximity & $\begin{array}{c}-265.4437 * * * \\
(87.3604)\end{array}$ & $\begin{array}{c}-314.6019 * * * \\
(94.3601)\end{array}$ & \\
\hline ACT Score & $\begin{array}{c}-22.3277^{*} \\
(12.0544)\end{array}$ & $\begin{array}{l}-17.8742 \\
(12.3481)\end{array}$ & \\
\hline ND/MN Resident & $\begin{array}{l}-1100.1749 * * * \\
(303.7341)\end{array}$ & $\begin{array}{l}-1101.1998 * * * \\
(302.1813)\end{array}$ & \\
\hline Parental Income (\$1000) & $\begin{array}{l}-0.0830 \\
(1.0192)\end{array}$ & $\begin{array}{c}0.0940 \\
(1.0041)\end{array}$ & \\
\hline Student Income $(\$ 1000)$ & $\begin{array}{c}36.9942 * * \\
(16.1932)\end{array}$ & $\begin{array}{c}35.5952 * * \\
(15.9145)\end{array}$ & \\
\hline Scholarships (\$1000) & $\begin{array}{c}-125.8891 * * * \\
(18.6068)\end{array}$ & $\begin{array}{c}-125.4705^{* * *} \\
(18.7202)\end{array}$ & \\
\hline $5 \mathrm{~K}<\mathrm{EFC}<=10 \mathrm{~K}$ & $\begin{array}{c}185.1204 \\
(164.9868)\end{array}$ & $\begin{array}{c}207.9525 \\
(167.2708)\end{array}$ & \\
\hline $10 \mathrm{~K}<\mathrm{EFC}<=15 \mathrm{~K}$ & $\begin{array}{c}-46.5374 \\
(195.7624)\end{array}$ & $\begin{array}{c}-6.0867 \\
(198.3916)\end{array}$ & \\
\hline $15 \mathrm{~K}<\mathrm{EFC}$ & $\begin{array}{l}-102.2696 \\
(181.7709)\end{array}$ & $\begin{array}{c}-45.9846 \\
(184.1372)\end{array}$ & \\
\hline Treatment Group & $\begin{array}{c}956.5673 * * * \\
(179.8774)\end{array}$ & $\begin{array}{c}952.9173 * * * \\
(179.8528)\end{array}$ & \\
\hline Group X 2007 & $\begin{array}{l}-424.5820 * \\
(216.4603)\end{array}$ & $\begin{array}{c}-438.4953 * * \\
(215.0383)\end{array}$ & $\begin{array}{l}-360.379 * \\
(204.597)\end{array}$ \\
\hline Group X 2008 & $\begin{array}{c}-564.3414 * * * \\
(210.0276)\end{array}$ & $\begin{array}{c}-580.2757 * * * \\
(209.4543)\end{array}$ & $\begin{array}{c}-594.616^{* * *} \\
(190.203)\end{array}$ \\
\hline Year 2007 & $\begin{array}{c}-31.5974 \\
(148.8099)\end{array}$ & $\begin{array}{c}104.3285 \\
(168.2134)\end{array}$ & \\
\hline Year 2008 & $\begin{array}{c}-93.1299 \\
(139.8650)\end{array}$ & $\begin{array}{c}-13.3127 \\
(144.1444)\end{array}$ & \\
\hline First Generation & & $\begin{array}{l}340.7158^{* *} \\
(135.5759)\end{array}$ & \\
\hline Number of Contacts & & $\begin{array}{l}-35.8464 \\
(24.7686)\end{array}$ & \\
\hline Constant & $\begin{array}{c}2211.1154 * * * \\
(449.9611)\end{array}$ & $\begin{array}{c}2103.4499 * * * \\
(438.8251)\end{array}$ & \\
\hline Observations & 2961 & 2961 & $1915 ; 2000$ \\
\hline Adjusted R-squared & 0.062 & 0.064 & $0.026 ; 0.033$ \\
\hline
\end{tabular}

Note: Robust standard errors clustered by high school appear in parentheses

$*, * *, * * *$ Statistically different from zero at the $10 \%, 5 \%$, and $1 \%$ level

(3) PSM ran separately on the 2006 \& 2007 samples and $2006 \& 2008$ samples.

Standard errors of PSM are bootstrapped using 100 iterations and clustered by high school. 
Table 5: Impact on Borrowing by EFC Group

\begin{tabular}{|c|c|c|}
\hline & (1) & (2) \\
\hline & $\begin{array}{c}\text { Total } \\
\text { Borrowing }\end{array}$ & $\begin{array}{c}\text { Private Loan } \\
\text { Borrowing }\end{array}$ \\
\hline Close Proximity & $\begin{array}{c}-782.7700 * * * \\
(170.9466)\end{array}$ & $\begin{array}{c}-272.1303 * * * \\
(87.7653)\end{array}$ \\
\hline ACT Score & $\begin{array}{c}-90.1301 * * * \\
(16.6947)\end{array}$ & $\begin{array}{c}-21.1498 * \\
(11.7056)\end{array}$ \\
\hline ND/MN Resident & $\begin{array}{c}-1468.5430 * * * \\
(360.7992)\end{array}$ & $\begin{array}{c}-1092.6515^{* * *} \\
(304.4270)\end{array}$ \\
\hline $\begin{array}{l}\text { Parental Income } \\
(\$ 1000)\end{array}$ & $\begin{array}{c}1.1613 \\
(1.6342)\end{array}$ & $\begin{array}{c}0.3869 \\
(0.9437)\end{array}$ \\
\hline $\begin{array}{l}\text { Student Income } \\
(\$ 1000)\end{array}$ & $\begin{array}{c}44.3648 * * * \\
(12.7368)\end{array}$ & $\begin{array}{c}38.8991 * * \\
(16.7457)\end{array}$ \\
\hline Scholarships (\$1000) & $\begin{array}{c}-269.4561 * * * \\
(23.7263)\end{array}$ & $\begin{array}{c}-127.9675^{* * *} \\
(15.6397)\end{array}$ \\
\hline Treatment Group & $\begin{array}{c}4147.6737 * * * \\
(437.0607)\end{array}$ & $\begin{array}{c}702.0451 * * * \\
(260.8204)\end{array}$ \\
\hline $\mathrm{EFC}$ & $\begin{array}{c}593.0093 \\
(393.7781)\end{array}$ & $\begin{array}{l}421.7457 * \\
(243.9187)\end{array}$ \\
\hline Group X 2007 & $\begin{array}{c}2700.8391 * * * \\
(599.4012)\end{array}$ & $\begin{array}{c}259.5936 \\
(356.6395)\end{array}$ \\
\hline Group X 2008 & $\begin{array}{c}2858.6430 * * * \\
(568.4619)\end{array}$ & $\begin{array}{l}-197.6120 \\
(351.9176)\end{array}$ \\
\hline Year 2007 & $\begin{array}{l}-511.2099 \\
(378.1495)\end{array}$ & $\begin{array}{c}-88.9663 \\
(190.2058)\end{array}$ \\
\hline Year 2008 & $\begin{array}{l}-416.1393 \\
(372.3644)\end{array}$ & $\begin{array}{c}36.2043 \\
(198.6611)\end{array}$ \\
\hline Group X EFC & $\begin{array}{c}1135.9338 * * \\
(518.3327)\end{array}$ & $\begin{array}{c}260.8403 \\
(331.1014)\end{array}$ \\
\hline EFC X Year 2007 & $\begin{array}{c}791.0814 \\
(522.5794)\end{array}$ & $\begin{array}{c}88.3907 \\
(307.5232)\end{array}$ \\
\hline EFC X Year 2008 & $\begin{array}{c}485.4967 \\
(437.2816)\end{array}$ & $\begin{array}{l}-205.8456 \\
(274.3527)\end{array}$ \\
\hline EFC X Group X 2007 & $\begin{array}{c}-2367.0008 * * * \\
(698.2371)\end{array}$ & $\begin{array}{c}-857.3051 * * \\
(430.4582)\end{array}$ \\
\hline EFC X Group X 2008 & $\begin{array}{c}-1370.4611^{* *} \\
(679.0777)\end{array}$ & $\begin{array}{l}-417.1630 \\
(439.5526)\end{array}$ \\
\hline Constant & $\begin{array}{c}4764.3394 * * * \\
\quad(651.0226)\end{array}$ & $\begin{array}{c}1834.2572 * * * \\
(473.8996)\end{array}$ \\
\hline Observations & 2961 & 2961 \\
\hline
\end{tabular}


Adjusted R-squared

0.424

0.063

Note: Robust standard errors clustered by high school appear in parentheses

$*, * *, * * *$ Statistically different from zero at the $10 \%, 5 \%$, and $1 \%$ level 
Table 6: Impact on Freshmen Cumulative GPA

\begin{tabular}{|c|c|c|c|}
\hline & $(1)$ & $(2)$ & (3) \\
\hline High School GPA & $\begin{array}{l}0.0023 * \\
(0.0012)\end{array}$ & $\begin{array}{c}0.0023^{* *} \\
(0.0012)\end{array}$ & \\
\hline Female & $\begin{array}{c}0.2926 * * * \\
(0.0245)\end{array}$ & $\begin{array}{c}0.2771 * * * \\
(0.0249)\end{array}$ & \\
\hline Minority Student & $\begin{array}{c}-0.2924 * * * \\
(0.0779)\end{array}$ & $\begin{array}{c}-0.2762 * * * \\
(0.0793)\end{array}$ & \\
\hline Close Proximity & $\begin{array}{c}-0.0928 * * * \\
(0.0336)\end{array}$ & $\begin{array}{c}-0.0643 * * \\
(0.0326)\end{array}$ & \\
\hline ACT Score & $\begin{array}{c}0.0647 * * * \\
(0.0038)\end{array}$ & $\begin{array}{c}0.0633 * * * \\
(0.0040)\end{array}$ & \\
\hline ND/MN Resident & $\begin{array}{c}0.0070 \\
(0.0513)\end{array}$ & $\begin{array}{c}0.0154 \\
(0.0508)\end{array}$ & \\
\hline Parental Income (\$1000) & $\begin{array}{c}0.0007 * * \\
(0.0003)\end{array}$ & $\begin{array}{c}0.0006 * * \\
(0.0003)\end{array}$ & \\
\hline Student Income (\$1000) & $\begin{array}{c}0.0035 \\
(0.0026)\end{array}$ & $\begin{array}{c}0.0039 \\
(0.0025)\end{array}$ & \\
\hline Scholarships $(\$ 1000)$ & $\begin{array}{c}0.0557 * * * \\
(0.0062)\end{array}$ & $\begin{array}{c}0.0543 * * * \\
(0.0061)\end{array}$ & \\
\hline $5 \mathrm{~K}<\mathrm{EFC}<=10 \mathrm{~K}$ & $\begin{array}{c}0.1696^{* * *} \\
(0.0512)\end{array}$ & $\begin{array}{c}0.1594 * * * \\
(0.0512)\end{array}$ & \\
\hline $10 \mathrm{~K}<\mathrm{EFC}<=15 \mathrm{~K}$ & $\begin{array}{c}0.2171 * * * \\
(0.0491)\end{array}$ & $\begin{array}{c}0.2004 * * * \\
(0.0498)\end{array}$ & \\
\hline $15 \mathrm{~K}<\mathrm{EFC}$ & $\begin{array}{c}0.2437 * * * \\
(0.0542)\end{array}$ & $\begin{array}{c}0.2210^{* * *} \\
(0.0543)\end{array}$ & \\
\hline Treatment Group & $\begin{array}{c}0.0157 \\
(0.0522)\end{array}$ & $\begin{array}{c}0.0147 \\
(0.0521)\end{array}$ & \\
\hline Group X 2007 & $\begin{array}{c}-0.1632 * * \\
(0.0681)\end{array}$ & $\begin{array}{c}-0.1557 * * \\
(0.0666)\end{array}$ & $\begin{array}{c}-.181 * * * \\
(.087)\end{array}$ \\
\hline Group X 2008 & $\begin{array}{l}-0.1111 \\
(0.0749)\end{array}$ & $\begin{array}{l}-0.1016 \\
(0.0741)\end{array}$ & $\begin{array}{l}-.124 \\
(.126)\end{array}$ \\
\hline Year 2007 & $\begin{array}{c}0.0058 \\
(0.0535)\end{array}$ & $\begin{array}{c}-0.0908 \\
(0.0611)\end{array}$ & \\
\hline Year 2008 & $\begin{array}{l}-0.0247 \\
(0.0608)\end{array}$ & $\begin{array}{l}-0.0776 \\
(0.0642)\end{array}$ & \\
\hline Stem Major & & $\begin{array}{l}-0.0343 \\
(0.0324)\end{array}$ & \\
\hline First Generation & & $\begin{array}{c}-0.0662 * * \\
(0.0300)\end{array}$ & \\
\hline Number of Contacts & & $\begin{array}{c}0.0265^{* * *} \\
(0.0071)\end{array}$ & \\
\hline Constant & $0.9776 * * *$ & $0.9699 * * *$ & \\
\hline
\end{tabular}


$(0.1122) \quad(0.1119)$

Observations $\quad 2920 \quad 2920 \quad 1876 ; 1972$

Adjusted R-squared $\quad 0.220 \quad 0.225 \quad 0.020 ; 0.015$

Note: Robust standard errors clustered by high school appear in parentheses $*, * *, * * *$ Statistically different from zero at the $10 \%, 5 \%$, and $1 \%$ level

(3) PSM ran separately on the $2006 \& 2007$ samples and $2006 \& 2008$

samples. Standard errors of PSM are bootstrapped using 100 iterations and clustered by high school. 
Table 7: Impact on Freshmen Credits Completed

\begin{tabular}{|c|c|c|c|}
\hline & (1) & (2) & (3) \\
\hline High School GPA & $\begin{array}{c}0.0094 \\
(0.0086)\end{array}$ & $\begin{array}{c}0.0094 \\
(0.0084)\end{array}$ & \\
\hline Female & $\begin{array}{c}1.8221^{* * *} \\
(0.1949)\end{array}$ & $\begin{array}{c}1.6613 * * * \\
(0.1952)\end{array}$ & \\
\hline Minority Student & $\begin{array}{c}-2.9316^{* * *} \\
(0.5610)\end{array}$ & $\begin{array}{c}-2.8009 * * * \\
(0.5728)\end{array}$ & \\
\hline Close Proximity & $\begin{array}{c}-1.4665^{* * *} \\
(0.2581)\end{array}$ & $\begin{array}{c}-1.2709 * * * \\
(0.2676)\end{array}$ & \\
\hline ACT Score & $\begin{array}{c}0.3628^{* * *} \\
(0.0318)\end{array}$ & $\begin{array}{c}0.3588 * * * \\
(0.0341)\end{array}$ & \\
\hline ND/MN Resident & $\begin{array}{l}-0.6724 \\
(0.4488)\end{array}$ & $\begin{array}{c}-0.6196 \\
(0.4418)\end{array}$ & \\
\hline Parental Income (\$1000) & $\begin{array}{c}0.0047 * * \\
(0.0020)\end{array}$ & $\begin{array}{c}0.0044 * * \\
(0.0020)\end{array}$ & \\
\hline Student Income $(\$ 1000)$ & $\begin{array}{c}0.0450 * * * \\
(0.0159)\end{array}$ & $\begin{array}{c}0.0489 * * * \\
(0.0156)\end{array}$ & \\
\hline Scholarships (\$1000) & $\begin{array}{c}0.3879 * * * \\
(0.0525)\end{array}$ & $\begin{array}{c}0.3780 * * * \\
(0.0524)\end{array}$ & \\
\hline $5 \mathrm{~K}<\mathrm{EFC}<=10 \mathrm{~K}$ & $\begin{array}{c}1.7155^{* * *} \\
(0.3837)\end{array}$ & $\begin{array}{c}1.6403 * * * \\
(0.3832)\end{array}$ & \\
\hline $10 \mathrm{~K}<\mathrm{EFC}<=15 \mathrm{~K}$ & $\begin{array}{c}1.6950 * * * \\
(0.4454)\end{array}$ & $\begin{array}{c}1.5581 * * * \\
(0.4432)\end{array}$ & \\
\hline $15 \mathrm{~K}<\mathrm{EFC}$ & $\begin{array}{c}1.8860 * * * \\
(0.4234)\end{array}$ & $\begin{array}{c}1.7022 * * * \\
(0.4228)\end{array}$ & \\
\hline Treatment Group & $\begin{array}{c}0.1708 \\
(0.4866)\end{array}$ & $\begin{array}{c}0.1464 \\
(0.4869)\end{array}$ & \\
\hline Group X 2007 & $\begin{array}{c}-1.0598 * \\
(0.5769)\end{array}$ & $\begin{array}{l}-0.9867 * \\
(0.5772)\end{array}$ & $\begin{array}{c}-1.210^{*} \\
(.694)\end{array}$ \\
\hline Group X 2008 & $\begin{array}{c}-1.1135 * \\
(0.5721)\end{array}$ & $\begin{array}{c}-1.0238 * \\
(0.5735)\end{array}$ & $\begin{array}{c}-1.352^{* *} \\
(.611)\end{array}$ \\
\hline Year 2007 & $\begin{array}{c}0.2514 \\
(0.4988)\end{array}$ & $\begin{array}{c}-0.4788 \\
(0.5426)\end{array}$ & \\
\hline Year 2008 & $\begin{array}{c}0.6333 \\
(0.4672)\end{array}$ & $\begin{array}{c}0.2293 \\
(0.5012)\end{array}$ & \\
\hline Stem Major & & $\begin{array}{l}-0.5041 * \\
(0.2624)\end{array}$ & \\
\hline First Generation & & $\begin{array}{c}-0.6456^{* *} \\
(0.2710)\end{array}$ & \\
\hline Number of Contacts & & $\begin{array}{c}0.1954 * * * \\
(0.0596)\end{array}$ & \\
\hline Constant & $15.0922 * * *$ & $15.0367 * * *$ & \\
\hline
\end{tabular}




\begin{tabular}{lccc} 
& $(1.0131)$ & $(1.0171)$ & \\
Observations & 2920 & 2920 & $1876 ; 1972$ \\
Adjusted R-squared & 0.141 & 0.146 & $0.010 ; 0.013$ \\
\hline
\end{tabular}

Note: Robust standard errors clustered by high school appear in parentheses $*, * *, * * *$ Statistically different from zero at the $10 \%, 5 \%$, and $1 \%$ level

(3) PSM ran separately on the 2006 \& 2007 samples and 2006 \& 2008 samples. Standard errors of PSM are bootstrapped using 100 iterations and clustered by high school. 
Table 8: Impact on Freshmen Stopout

\begin{tabular}{|c|c|c|c|}
\hline & (1) & (2) & (3) \\
\hline High School GPA & $\begin{array}{c}-0.9090 * * * \\
(0.1245)\end{array}$ & $\begin{array}{c}-0.9173 * * * \\
(0.1251)\end{array}$ & \\
\hline Female & $\begin{array}{c}0.1105 \\
(0.1138)\end{array}$ & $\begin{array}{c}0.1484 \\
(0.1101)\end{array}$ & \\
\hline Minority Student & $\begin{array}{c}0.3994 \\
(0.2494)\end{array}$ & $\begin{array}{c}0.3747 \\
(0.2541)\end{array}$ & \\
\hline Close Proximity & $\begin{array}{c}0.0924 \\
(0.0907)\end{array}$ & $\begin{array}{c}0.0862 \\
(0.0928)\end{array}$ & \\
\hline ACT Score & $\begin{array}{c}0.0232 \\
(0.0158)\end{array}$ & $\begin{array}{c}0.0206 \\
(0.0162)\end{array}$ & \\
\hline ND/MN Resident & $\begin{array}{l}-0.1798 \\
(0.1961)\end{array}$ & $\begin{array}{l}-0.1662 \\
(0.1996)\end{array}$ & \\
\hline Parental Income (\$1000) & $\begin{array}{l}-0.0007 \\
(0.0011)\end{array}$ & $\begin{array}{l}-0.0005 \\
(0.0010)\end{array}$ & \\
\hline Student Income (\$1000) & $\begin{array}{l}0.0144^{*} \\
(0.0080)\end{array}$ & $\begin{array}{c}0.0136^{*} \\
(0.0082)\end{array}$ & \\
\hline Scholarships (\$1000) & $\begin{array}{c}-0.0939 * * * \\
(0.0285)\end{array}$ & $\begin{array}{c}-0.0959 * * * \\
(0.0286)\end{array}$ & \\
\hline $5 \mathrm{~K}<\mathrm{EFC}<=10 \mathrm{~K}$ & $\begin{array}{c}-0.4845 * * * \\
(0.1830)\end{array}$ & $\begin{array}{c}-0.4828 * * * \\
(0.1855)\end{array}$ & \\
\hline $10 \mathrm{~K}<\mathrm{EFC}<=15 \mathrm{~K}$ & $\begin{array}{c}-0.4014^{* *} \\
(0.1713)\end{array}$ & $\begin{array}{c}-0.3790 * * \\
(0.1726)\end{array}$ & \\
\hline $15 \mathrm{~K}<\mathrm{EFC}$ & $\begin{array}{c}-0.5806^{* * *} \\
(0.1758)\end{array}$ & $\begin{array}{c}-0.5518 * * * \\
(0.1776)\end{array}$ & \\
\hline Treatment Group & $\begin{array}{c}0.3376 \\
(0.2292)\end{array}$ & $\begin{array}{c}0.3497 \\
(0.2275)\end{array}$ & \\
\hline Group X 2007 & $\begin{array}{c}0.4497 \\
(0.3444)\end{array}$ & $\begin{array}{c}0.4293 \\
(0.3390)\end{array}$ & $\begin{array}{l}0.042 \\
(.032)\end{array}$ \\
\hline Group X 2008 & $\begin{array}{l}-0.2434 \\
(0.2790)\end{array}$ & $\begin{array}{l}-0.2594 \\
(0.2767)\end{array}$ & $\begin{array}{l}-0.018 \\
(0.035)\end{array}$ \\
\hline Year 2007 & $\begin{array}{l}-0.5867 * \\
(0.3255)\end{array}$ & $\begin{array}{l}-0.5330 \\
(0.3300)\end{array}$ & \\
\hline Year 2008 & $\begin{array}{c}0.2639 \\
(0.2385)\end{array}$ & $\begin{array}{c}0.2947 \\
(0.2406)\end{array}$ & \\
\hline Stem Major & & $\begin{array}{c}0.1996 \\
(0.1243)\end{array}$ & \\
\hline First Generation & & $\begin{array}{c}0.2957 * * * \\
(0.1136)\end{array}$ & \\
\hline Number of Contacts & & $\begin{array}{l}-0.0103 \\
(0.0269)\end{array}$ & \\
\hline Constant & $1.4889 * * *$ & $1.4258^{* * *}$ & \\
\hline
\end{tabular}




\begin{tabular}{lccc} 
& $(0.4918)$ & $(0.5039)$ & \\
Observations & 2920 & 2920 & $1876 ; 1972$ \\
Pseudo R2 & 0.053 & 0.056 & $.013 ; .004$ \\
\hline
\end{tabular}

Note: Robust standard errors clustered by high school appear in parentheses $*, * *, * * *$ Statistically different from zero at the $10 \%, 5 \%$, and $1 \%$ level

(3) PSM ran separately on the 2006 \& 2007 samples and 2006 \& 2008 samples. Standard errors of PSM are bootstrapped using 100 iterations and clustered by high school. 
Figure 1: Borrowing by Group - Pre/Post Policy Changes
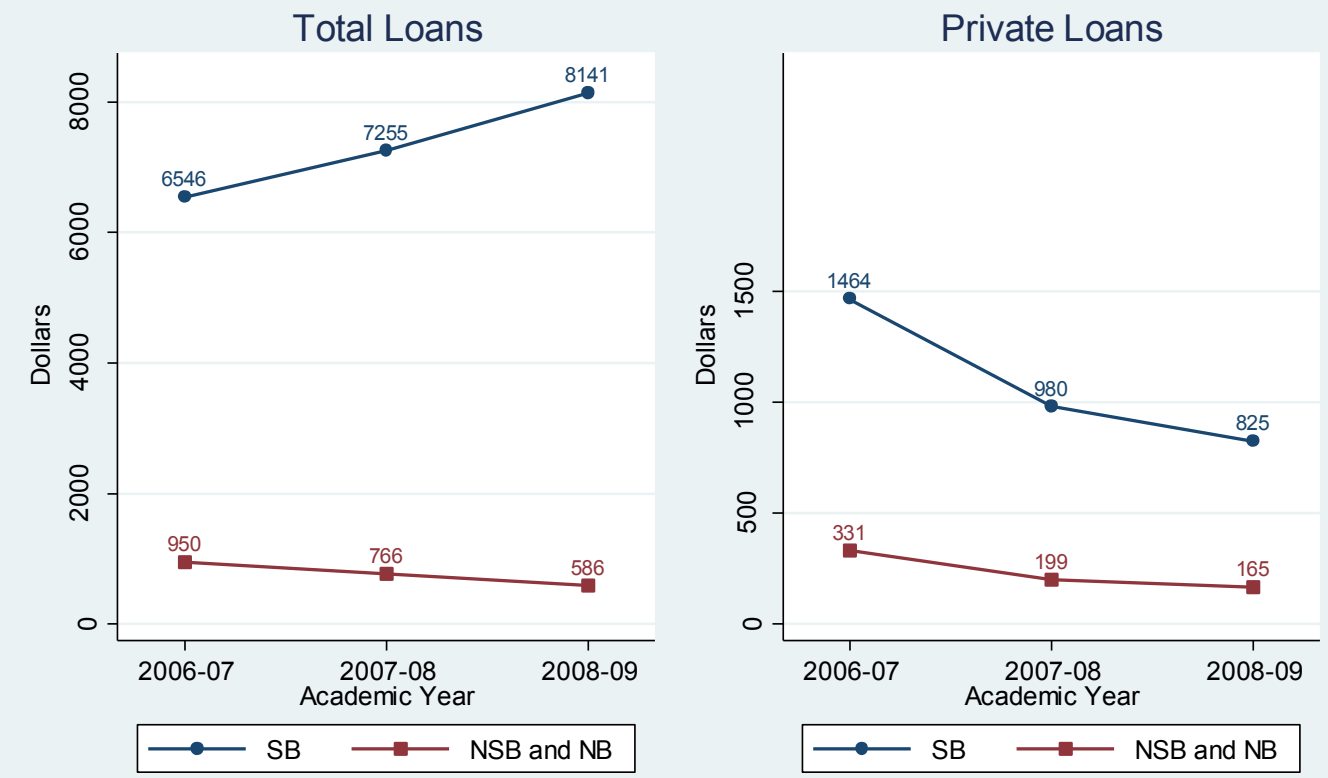

Treatment Group: SB Stafford Borrower

Control Group: NSB Non-Stafford Borrower and NB Non-Borrower 


\section{Figure 2: Macroeconomic Conditions}

(a). Unemployment Rates: 2000-2014

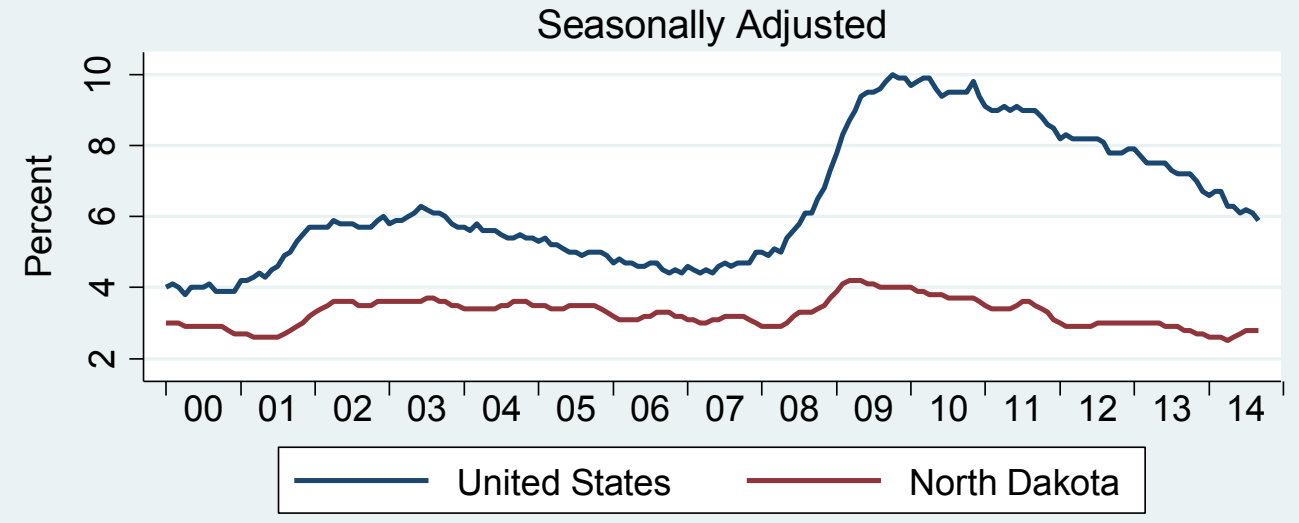

Source: US Bureau of Labor Statistics - Local Area Unemployment Statistics

(b). Real GDP Growth Rate: 2000-2013 2009 Chained Dollars

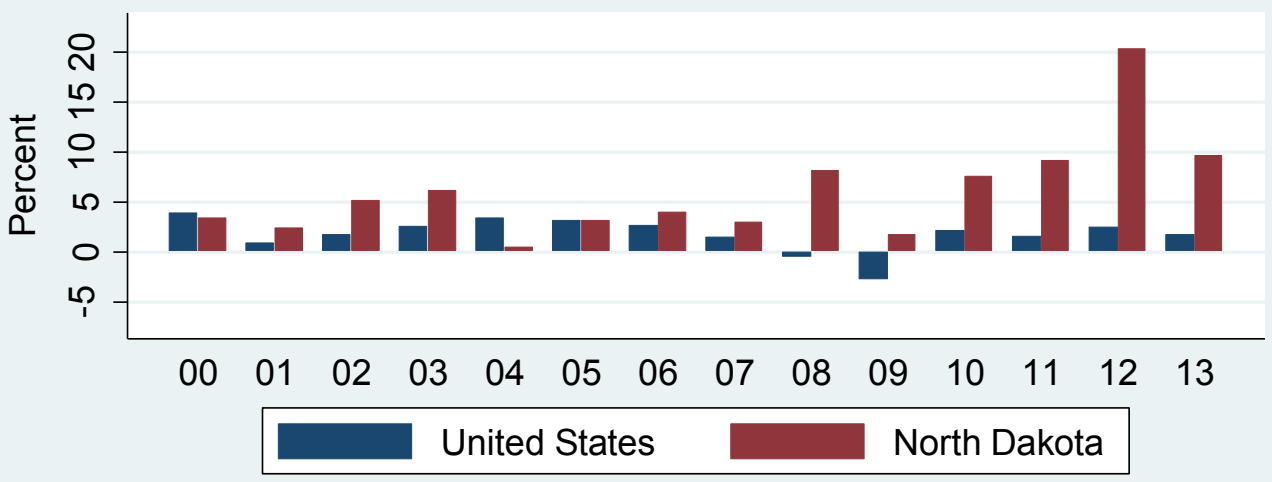

Source: U.S. Bureau of Economic Analysis

(c). Housing Price Indices: 2000-2014

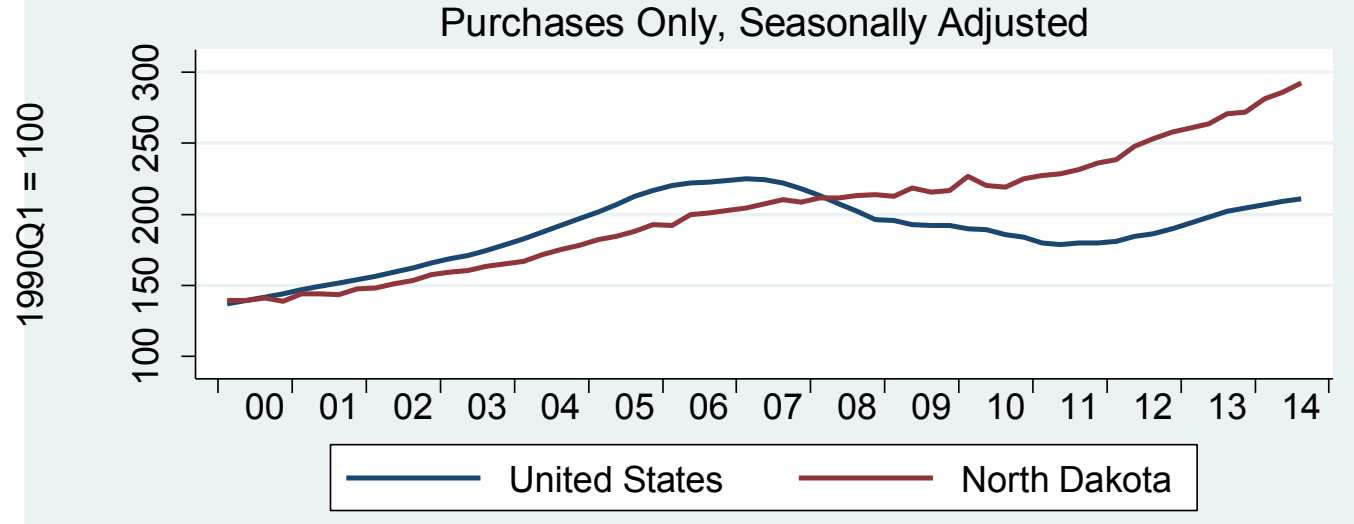

Source: Federal Housing Finance Agency 
Figure 3: Performance by Group - Pre/Post Policy Changes
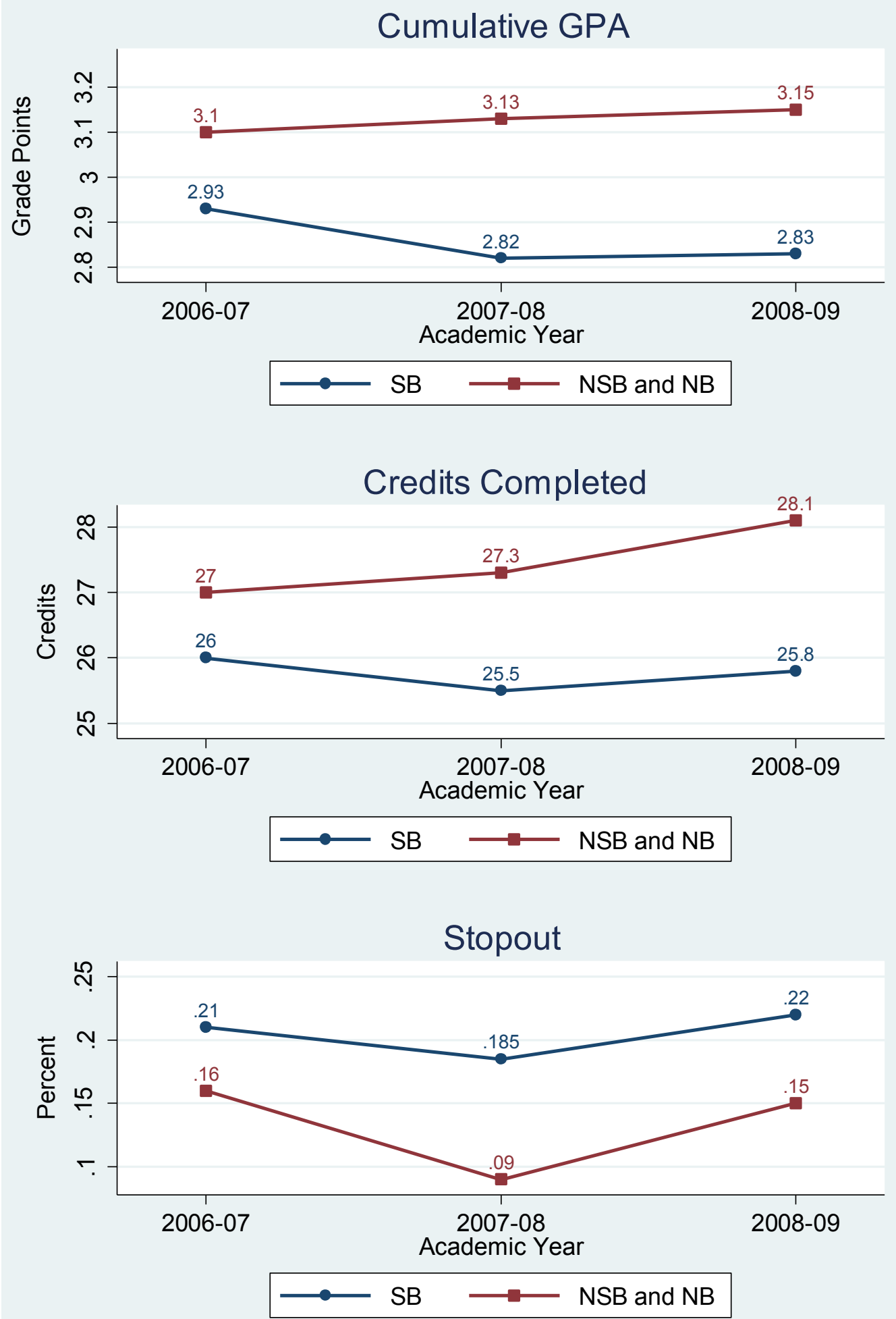

Treatment Group: SB = Stafford Borrower

Control Group: NSB $=$ Non-Stafford Borrower and NB $=$ Non-Borrower 
Figure 3: Performance by Group - Pre/Post Policy Changes
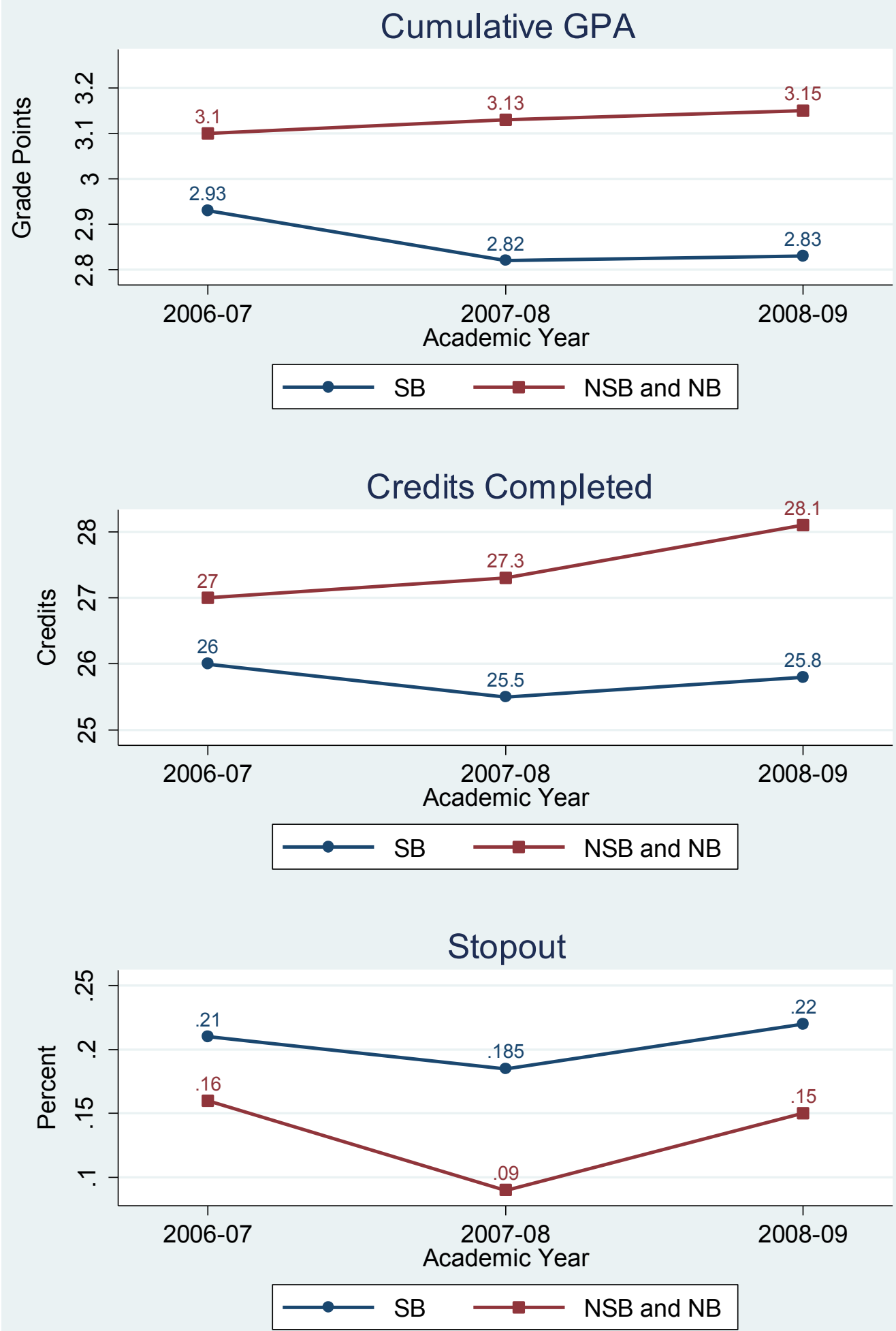

Treatment Group: SB Stafford Borrower Control Group: NSB Non-Stafford Borrower and NB Non-Borrower 


\section{References.}

Belley, Philippe, and Lance Lochner. 2007. The changing role of family income and ability in determining educational achievement. Journal of Human Capital 1, no. 1:37-89.

Brown, Meta, John Karl Scholz, and Ananth Seshardi. 2012. A new test of borrowing constraints for education. Review of Economic Studies 79, no. 2:511-538.

Cameron, Stephen V., and Christopher Taber. 2004. Estimation of educational borrowing constraints using returns to schooling. Journal of Political Economy 12, no. 1:132-182.

Card, David. (2001). Estimating the return to schooling: progress on some persistent econometric problems, Econometrica, 69, no. 5:1127-1160.

Carneiro, Pedro, and James J. Heckman. 2002. The evidence on credit constraints in postsecondary schooling. Economic Journal 112, no. 482: 705-734.

College Board. 2012. Trends in Student Aid, 2013. New York: College Board.

Deaton, Angus. 1991. Saving and liquidity constraints. Econometrica 59, no 5:1221-1248.

Lochner, Lance, and Alexander Monge-Naranjo. 2011. The nature of credit constraints and human capital. American Economic Review 101, no. 6: 2487-2529

Stinebrickner, Ralph, and Todd Stinebrickner. 2008. The effect of credit constraints on the college drop-out decision: A direct approach using a new panel study. American Economic Review 98, no. 5:2163-2184

Snyder, T.D., and Dillow, S.A. 2013. Digest of Education Statistics 2012 (NCES 2014-015). National Center for Education Statistics, Institute of Education Sciences, U.S. Department of Education. Washington, DC.

Wei, Christina C., and Paul Skomsvold, 2011. Borrowing at the Maximum: Undergraduate Student Loan Borrowers in 2007-08. NCES 2012-161. National Center for Education Statistics, U.S. Department of Education. Washington, DC. 
